\title{
DAKWAH DI TURKI PADA MASA DINASTI UTSMANI
}

\author{
Desi Syafriani \\ IAIN Bukittinggi, desisyafriani06@gmail.com \\ Doni Nofra \\ LAIN Bukittinggi,doninofra25@gmail.com
}

\begin{abstract}
The Ottoman dynasty was a dynasty that was quite involved in the development and spread of Islam in Asia, Africa and Europe. The Ottoman dynasty emerged in Turkey when the Islamic world suffered a setback, namely the second period of the Abbasid dynasty, estimated in the 9th century AD. In the development of da'wah in Turkey, the strategy used is not to force in da'wah and to show an attitude of tolerance, through this da'wah strategy in Turkey can run well. In addition to this strategy we must know about the character and character of the Turkish people, namely discipline and obedience to the rules in force. Da'wah activities and developments in Turkey are supported by Catholicism. During his time, Dakwan's activities during the Ottoman period were able to bring Islam to various parts of the Balkan countries such as Bosni, Serbia and Crete.
\end{abstract}

Keywords: Justice, Inheritance Law, Islam.

\begin{abstract}
Abstrak
Dinasti Turki Usmani merupakan dinasti yang cukup andil dalam perkembangan dan penyebaran agama Islam di Asia, Afrika dan Eropa. Dinasti Utsmani muncul di Turki saat dunia Islam mengalami kemunduran yaitu periode ke dua pemerintahan dinasti Abbasiyah diperkirakan pada abad ke 9 M. Dinasti ini didirikan oleh bangsa Turki dari kabila Oqhus yang tinggal di wilayah Mongol dan bagian utara negeri Cina. Dalam perkembangan dakwah di Turki, strategi yang digunakan adalah tidak memaksa dalam berdakwah dan menunjukan sikeap toleransi, melalui strategi ini dakwah di Turki dapat berjalan dengan baik. Selain strategi ini kita mesti tau tentang karakter dan watak orang-orang Turki yaitu disiplin dan taat kepada aturan yang berlaku. Kegiatan dan perkembangan dakwah di Turki didukung oleh agama Katolik. Pada masanya, aktivitas Dakwan pada masa Dinasti Usmani mampu membawa Islam ke berbagai belahan negera Balkan seperti Bosni, Serbia, dan Kreta.
\end{abstract}

Kata Kunci: Dakwah, Dinasti Utsmani, Turki

\section{PENDAHULUAN}

Berbicara tentang kerajaan Utsmani, yang sering disebut dengan kerajaan Turki Usmani merupakan hal yang tidak bisa kita lupakan sepanjang perkembangan Islam. Dinasti Turki Usmani merupakan dinasti yang cukup andil dalam perkembangan dan penyebaran agama Islam di
Asia, Afrika dan Eropa. Kalau kita melihat perkembangan Islam, bangsa Turki sangat berperan penting.

Dinasti Utsmani muncul di Turki saat dunia Islam mengalami kemunduran yaitu periode ke dua pemerintahan dinasti Abbasiyah diperkirakan pada abad ke 9 M. Pada abad ke 9 ini muncul berbagai 
dinasti seperti Bani Tulun di Mesir 858-905 M, Aghlab di Khairawan, 800-809 M, Bani Buwaihi di Baghdad dan Syirad 932-1000M, juga Bani Saman di Bukhara 874-1001 M. Turki Utsmani berkuasa di Asia Kecil ketika datangnya pembina Ottoman tahun $1306 \mathrm{M}$, nama ini diambil dari keturunan Usman I sebagai pendiri dinasti ini dan berkuasa sampai tahun $1922 \mathrm{M}$.

Melihat sejarah, Turki Utsmani merupakan kerajaan yang paling lama berkuasa. Kita lihat kerajaan Utsmani pada masa Sultan Usman, orang Turki tidak merebut negara-negara Arab melainkan juga seluruh daerah Kaukasus dan Kota Wina. Dari ibu kota kerajaan tersebut (Istambul), mereka dapat menguasai daerah-daerah di sekitar laut tengah, penguasaan ini berjalan cukup lama sehingga Turki menjadi sektor pentig dalam perkembangan politik di bagian Eropa Barat.

\section{BERDIRINYA DINASTI UTSMANI}

Dinasti ini didirikan oleh bangsa Turki dari kabila Oqhus yang tinggal di wilayah Mongol dan bagian utara negeri Cina. Bangsa ini tinggal di wilayah Mungol kira-kira tiga ratus tahun, setelah itu mereka ke Turkistan dan ke Persia juga sampai Irak. Kalau kita melacak kapan mereka memeluk Islam, diperkirakan pada abad ke IX atau X Masehi yaitu ketika mereka menetap di wilayah Asia Tengah.

Pada saat seragan tentara Mongol abad XIII, untuk menyelamatkan diri, mereka pindah ke wilayah barat dan dengan saudara mereka yaitu orang-rang Turki Saljuk di dataran tinggi Asia Kecil. Mereka dipimpin oleh Ertughrul mengabdikan diri kepada bani Saljuk yang sedang berperang melawan Romawi Timur yang dipimpin oleh Sultan Alauddin II.

Semangat juang yang dilakukan untuk mengabdikan diri kepada Saljuk, mereka bisa memenagkan perperangan melawan Romawi Timur, atas bantuan dan keberhasilan itu mereka diberikan imbalan atau hadiah oleh Sultan Alauddin
II berupa tanah yang terletak di Asia Kecil berbatasan dengan wilayag Bizantium. Melalui wilayah yang dihadiakan oleh Sultan Alauddin II ini mereka mengembangkan wilayah tersebut dan membentuk kekuatan pemerintahan baru yang berpusat di Syuhud.

Tidak lama berjalan waktu, pada tahun 1300, muncul penyerangan dari kekuatan tentara Mongol terhadap Kesultanan Saljuk, pada saat penyerangan Mongol ini Alauddin II terbunuh oleh kekuatan tentara Mongol. Akibat terbunuhnya Alauddin II, kesultanan Saljuk ini terpecah menjadi kekuatan kerajaan kaci-kecil, mereka saling manyatakan diri untuk kemerdekaan pada sat itu, begitu juga dengan Utsmani menyatakan berkuasa terhadap wilayah yang mereka dudukinya, sejak peristiwa itulah muncul atau berdiri kerajaan Utsmani.

Pada masa awal berdirinya Utsmani ini, yang menjadi penguasa pertama adalah Utsman, sehingga digelari atau disebut dengan nama Utsmani I pada tahun $699 \mathrm{H}$ atau $1300 \mathrm{M}$. Pada masa pemerintahannya, kebijakan utama yang dilakukan adalah mempertahankan wilayah kekuasaan dan memperluas wilayah kekuasaan. Selanjutnya melakukan penyerangan terhadap wilayah di sekitar perbatasan Bizantium dan bisa mengalahkan wilayah Broessa tahun $1317 \mathrm{M}$. Tahun 1326 M, Kota Broessa dijadikan sebagai pusat kekuasaan Kesultanan Turki Utsmani.

Dinasti Utsmani di Turki merupakan dinasti terbesar yang kuat pengaruhnya dalam perkembangan wilayah Islam di kawasan Asia, Afrika dan Eropa. Turki memiliki peran penting dalam proses perkembangan Islam dan peradabannya. Kalau kita menelusuri tentang perann pentingnya dapat kita lihat peran khalifanya membantu pengembangan dinasti Abbasiyah, selain itu, walaupun pemerintahannya berdiri sendiri, mereka tetap tunduk dan loyal terhadap pemerintahan dinasti Abbasiyah. Dalam pemerintahan Abbasiyah dia disebut dengan 
kekuatan Bani Saljuk yang cukup berpengaruh dalam mempertahankan kekuasaan dinasti Abbasiyah.

Pemerintahan Utsmani semangkin kuat dan memperluas wilayah kekuasaanya, pada masa pemerintahan Orkhan, 1326-1359 M, dia dapat menaklukan Kota Azumia (1327 M), Tasasyani (1330 M), Uskandar (1328M), Ankara (1354 M), dan wilayah Gallipoli (1356 M). Wilayah yang ditaklukan ini adalah wilayah yang terletak di bagian Eropa yang pertama diduduki Utsmani. Pada masa kesultanan Murad I, (1359-1389 M), dia memokuskan pada pertahanan pemerintah dan mempertahankan wilayah yang sudah dikuasai. Murad I juga melakukan perluasan wilayah kekuasaan di samping mempertahankan wilayah yang ada. Murad I mampu menklukan wilayah yang ada di Benua Eropa seperti, Adrianopel, Macedonia, Sophia, Salonia, dan wilayah bagian Utara Yunani.

Melihat kekuatan yang dimiliki oleh Utsmani ini, Paus mengobarkan semangat kepada tentaranya untuk berperang melawan Utsmani dan mengusirnya dari wilayah Eropa. Kekuatan yang dibentuk Paus untuk menyerang kekuatan Utsmani ini dipimpin oleh Sijisman, beliau adalah seorang raja Hungaria. Kekuatan yang disusun oleh Paus ini mampuh dikalahkan oleh Utsmani yang pada saat itu dipimpin oleh Sultan Bayazid I, dia adalah pengganti Murad I (1389-1402 M). Peristiwa ini menjadi peristiwa yang sangat bersejarah dalam dunia Islam dan menjadi prestasi yang gemilang bagi umat Islam.

Turki Utsmani gemilang pada masa Sutan Muhammad II, nama dia dikenal dengan sebutan Al-Fatih yang berarti sang penakluk (1451-1481 M). Al-Fatih mampu menaklukan Romawi Timur (1453 M) yang menjadi pusat pemerintahannya adalah Konstatinopel, penaklikan kota ini tidak hannya pada masa Utsmani saja namun, jauh sebelumnya yaitu pada masa dinasti Umayyah sudah dilakukan, namun mereka gagal dalam penaklukan kota ini, baru pada masa Utsmani Konstatinopel mampuh ditaklukan.

Jatuhnya Konstatinopel ke tangan Utsmani, memberi hal yang positif dalam penyabaran Islam dan perluasan wilayah kekuasaan Turki Utsmani ke Benua Eropa. Eropa bagian timur terjadinya ekspansi sampai gerbang Kota Wina, Australia. Pada masa pemerintahan Sultan Salim I (1512-1519 M) terjadi peralihan wilaya yang akan dikuasai yaitu kebagian timur menaklukan Persia, Syiria dan Kota Mesir. Selanjutnya dikembangkan oleh Sulaiman alQanuni (1519-1566 M) melanjutkan perluasan wilayah kekuasaan Turki Utsmani yaitu menaklukan wilayah Irak, Belgrado, Pulau Rhodes, Tunisia, Budhapest, dan Yaman. Melalui penaklukan ini wilayah kekuasaan Turki Utsmani meliputi, Asia, Eropa dan Afrika. Asia terdiri dari, Asia Kecil, Irak, Syiria, Hijaz, dan Yaman. Afrika meliputi, Mesir, Libya, Tunisia, dan wilayah Aljazair. Bagian Eropa meliputi, Bulgariah, Yunani, Serbia, Montenegro (Yugoslavia), Armenia, Albania, Hungaria dan Rumania. Semua wilayah ini dikuasai pada masa pemimpin Sultan Sulaiman Al-Qanuni.

Kemunduran Turki Utsmani mulai tampak sejak meninggaknya Sulaiman Al-Qanuni, setelah beliau meninggal dunia wilayah kekuasan yang begitu luas menjadi perebutan bagi putra-putranya, meskipun ada perebutan kekuasaan dikalangan anak-anak AlQanuni, dinasti ini masih disegani dan merupakan negara yang kuat dalam bidang tentara atau kemiliterannya.

\section{PENAKLUKAN KONSTANTINOPEL}

Penaklukan Konstatinopel dilakukan oleh Sultan Muhammad II dan bala tentaranya. Kalau kita mengenal Konstatinopel, ini merupakan ibu kota Romawi Timur dan pusat pengembangan agama Katolik terbesar pada saat itu. Dalam penaklukan kota Konstatinopel Muhammad II membuat strategi perang terlebi dahulu yaitu membuat benteng-benteng pertahanan di perbatasan Konstatinopel dengan disen 
mengelilingi kekuasaan tersebut, pada awalnya strategi tersebut sulit untuk dilakukan karena tidak disetujuai pihak Konstatinopel, tapi karena kelicikan Sultan Muhammad II, dia mencanangkan bahwa benteng tersebut tujuannya untuk mengontrol dan mengawasi rakyatnya yang keluar dari wilayah kekuasaannya, begitu juga dengan rakyatnya yang masuk ke Eropa melalui daerah Bosporus.

Selesainya pembagunan benteng-benteng pertahanan di sekeliling Konstantinopel, mulailah digerakan para tentara oleh Muhammad II dengan jumla tentaranya 250.000 orang yang menjadi pimpinan perangnya adalah Sultan Muhammad II sendiri. Begitu kuatnya serangan dari Turki Utsmani membuat raja Konstantinus meminta bantuan kepada Paus di Roma dan raja-raja yang ada di Eropa, permintaan tersebut tidak mendapatkan respon yang baik. Kekuatan Konstantinus mendapat bantuan dari pasukan Vinesia karena mereka punya permasalahan dan kepentingan tersendiri berkaitan dengan wilayah Utsmani.

Bantuan yang diberikan oleh pasukan Vinesia adalah dengan cara membentangkan rantairantai besar untuk menghadang kapal-kapal Utsmani yang akan datang berlabuh di Bospourus. Kekuatan ini tidak berbuah hasil karena Sultan Muhammad II menarok kapal-kapalnya ke daratan dengan menggunakan bantal kayu-kayu besar dan menggeser kapalnya kearah barat kota.

Pada tanggal 28 Mei 1453, kota Konstantinopel mampuh ditaklukan oleh tentara Sultan Muhammad II dengan mengepung kota ini lebih kurang 53 hari dan serangan terhadap kekuatan kota ini tidak ada putus-putunya. Dalam peristiwa pengepungan dan serangan ini terbunuhlah raja Konstantinus IX. Masuklah Sultan Muhammad II dan bala tentaranya ke Konstantinopel lalu mengganti nama kota ini menjadi Istambul dan menjadikan ibu kota. Tempat ibadah orang Romawi yang dikenal dengan
Gereja Aya Sophia diganti dengan nama Masjid Aya Sophia yang dipergunakan untuk beribada bagi orang Islam. Selain itu dalam rangka mengenang keberhasilam Sultan Muhammad II didirikan pula sebuah mesjid di kota tersebut dengan nama Masjid Muhammad.

Runtuhnya kekuatan Romawi Timur memberi dampak besar kepada Turki Utsmani, karena menghubungkan Benua Eropa dan Asia sehingga terjadi percepatan dalam laju perjalanan dari Anatolia ke Eropa. Tahun berikutnya Sultan Muhammad II kembali melakukan perluasan wilayah ke negri Serbia, penaklukan ini berhasil dilakukannya. Satu persatu wilayah kembali ditaklukan oleh tentara Turki Utsmani seperti, Athena, Mora dan menyebarlah dakwah Islam secara pesat.

\section{STRATEGI DAKWAH DINASTI UTSMANI}

Pada masa kepemimpinan Utsman bin Ertughrul (1299-1326 M), banyak kemajuan yang dialami Turki Utsmani baik itu dakam bidang militer, pengetahuan agama, pemerintahan, budaya, serta dalam bidang dakwah. Untuk melihat perkembangan tersebut dapat kita lihat melalui keberhasilan yang dialami Turki Utsmani berikut ini.

\section{Dakwah dalam bidang Militer}

Dalam bidang militer, dakwah berkembang dengan baik yaitu pada kekuatan tentara Utsmani Jenissari atau pasukan Inkisyariah. Pasukan inidikenal dengan pasukan yang kuat dan memiliki strategi perang yang baik. Selain itu pasukan ini juga dikenal dengan pasukan mesin perang Utsmani untuk menklukan wilayah-wilayah nonmuslim yang menjadi sasaran dakwah Utsmani.

Selain dari pasukan Jenissari ada pasukan lain yang juga kuat dalam pemerintahan Utsmani, mereka adalah pasukan dari kelompok Fiodal yang dikirim untuk mempertahankan wilayah kekuasaan pemerintahan Utsmani dan mereka disebut dengan tentara Thaujiyah. Selain militer yang kuat dimiliki 
Turki Utsmani, kemajuan juga didukun melalui watak dan karakter orang Turki itu sendiri, mereka dikenal dengan orang yang disiplin, menghargai pimpinan, dan taat terhadap perinta pimpinannya.

Strategi dakwah yang dipakai dinasti Utsmani dalam bidang kemiliteran dan pemerintahan adalah dengan cara dakwah sruktural, dakwah ini dilakukan dalam masyarakat luas dan daerah yang dikuasainya. Dakwah dalam bidang struktural dilakukan dengan memperbaiki struktut pemerintahan Turki Utsmani dalam pemerintahannya.

Dalam bidang pemerintahan sultan sebagai pemegang pemerintahan dibantu oleh beberapa tingkatan seperti, Perdana Mentri (shadr al-azham), di bawanya Gubernur (pasya) yang bertugas mengatur dan mengurus wilayah tingkat I, di bawa gubernur ada beberapa orang yang ditunjuk, bupati (az-zanaziq atau al-alawiyah). Selain perbaikan struktural pemerintahan dibentuk pula atau disusun undang-undang pemerintahannya, tujuannya adalah menjadi kontrol dan payung hukum pemerintahan yang dijalani Utsmani. Undang-undang yang disusun tersebut diberi nama Multaqa Al-Abhur.

\section{Dakwah Dalam Bidang Keagamaan}

Perkembangan dakwah dalam bidang agama merupakan faktor terpenting dalam pemerintahan Turki utsmani karena melalui dakwah agama ini menentukan keterikatan antara pengikut dinasti Utsmani. Utsmani sangat terikat dengan syariat Islam sehingga fatwa ulama sangat dihargai dalam pemerintahannya. Dalam pemerintahan Utsmani, ulama berperan penting dalam kemajuan masyarakat. Pejabat pemerintahan dibidang agama dikenal dengan Mufti, dan berhak membarikan fatwa terhadap permasalahan dalam bidang agama dalam kehidupan. Mufti juga berperang segai legalitas hukum pemerintahan Turki Utsmani.

Kalau kita melihat perkembangan keagamaan ketika Turki Utsman, kehidupan keagamaannya berkembang dengan baik dan mengalami kemajuan termasuk perkembangan tarekat pada saat itu. Perkembangan tarekat pada saat itu terkenal dengan tarekat Bektasyi dan Maulawi, tarekat ini secara umum banyak ditekuni dan dipelajari dari kalangan militer dan sipil. Tarekat Bektasyi memiliki pengaruh yang kuat dalam kalangan Jenisseri, pengaruh yang kuat ini membuat sebutan mereka menjadi Bektasyi. Tarekat Maulawi dominan diminati dari kalangan penguasa yang tujuannya adalah untuk mengimbangi perkembangan tarekat Jenissari Bektasyi.

Walaupun perkembangan agama dalam keadaan baik pada masa pemerintahan Turki Utsmani, namun berkaitan dengan keahlian bidang agama seperti fiqh, ilmu kalam, tafsir, hadits tidak begitu tampak perkembangannya karena masingmasing pemimpin Utsmani memiliki kecendrungan untuk meyakini atau fanatik terhadap satu mazhab. Akibat penguasa fanatik terhadab satu mazhab atau aliran, perkembangan agama dalam bentuk ijtihat ulama tidak diperhatikan lagi, namun dalam pengembangan ilmu agama ulama tetap menulis buku-buku dalam bentuk penjelasan saja (syarh), dan catatan (hasyiyah) saja. Namun dalam perkembangan peradaban Islam tidak dapat kita pungkiri bahwa Turki Utsmani berperan penting dan sangat berjasa dalam penyebaran agama Islam.

\section{Dakwah Dalam Bidang Ilmu Pengetahuan}

Kalau kita melihat ilmu pengetahuan ketika dinasti Turki Utsani, sedikit sekali ilmuwan yang muncul pada saat ini karena Utsmani lebih fokus dalam bidang militer dibandingkan ilmu pengetahuan, tujuannya adalah perluasan wilayah kekuasaan. Dalam bidang ilmu pengetahuan tidak ditemukan atau tidak adah ahli pengetahuan yang menonjol pada masa dinasti Turki Utsmani ini. Berbicara tentang dakwah dalam bidang ilmu pengetahuan yaitu melalui sekolah-sekolah yang didirikan, melalui sekolah ini anak-anak mendapatkan ilmu pengetahuan. 


\section{Dakwah Dalam Bidang Kebudayaan}

Dakwah dalam bidang kebudayaan ini berkembang dengan baik, pada tahun 1582-1636 M, muncul salah seorang penyair yang bernama Nafi, ia bekerja pada pemerintahan Murad Pasya yaitu melalui karya-karya sastra yang ditulisnya dalam bentuk puisi atau dikenaljuga dalam bentuk qasidah, usahanya ini mendapat perhatian dari para sultan karena mengikat hati masyarakat dan sultan yang berkuasa pada saat itu.

Penyair yang terkenal pada masa Utsmani adalah, Yusuf Nabi (1642-1712 M), Yusuf dikenal dengan seorang juru tulis Musahif Mustafa, salah seorang mentri bangsa Persia. Ia terkenal dalam puisinya yang membuat sentuhan terhadap semua permasalahan dalam kehidupan, misalnya bidang agama, filsafat, dan romantisme. Dia juga menulis tentang biografi dan kisah-kisah sebuah perjalanan. Keilmuan lain yang terkenal adalah Mustafa bin Abdullah, ia terkenal dengan buku bergambar yang ditulisnya dengan judul Kasyf Az-Zunun fi Asmai Al-Kutub wa Al-Funun. Dia juga dikenal denga sebutan Haji Halife atau Katib Celebi. Karya lain beluau yang terkenal adalah buku biografi para penulis yang memuat lebih dari 1500 buku berbahas Turki, persia, dan Arab. Penyair lain yang terkenal adalah M. Esat Efendi, nama beliau dikenal dengan sebutan Galip Dede atau Syah Galib (17571799 M)

Selain dibidang yang ditulis di atas, ada keilmuan lain yaitu dalam bidang arsitektur, dalam bidang arsitektur yang pengaruh Utsmani tampak dari segi arsitektur masjid-masjid yang didirikan, seperti masjid Al-Muhammadi atau dikenal juga dengan sebutan masjid Sultan Muhammad Al-Fatih, masjid Agung Sultan Sulaiman, dan Masjid Aya Sophia. Selain masjid juga banyak yang dibangun seperti tempat pemandian, sekolah, rumah sakit, jembatan, villa, saluran air bersih, semua arsitektur bangunan ini dibangun dalam koordinator Sinan, beliau adalah arsitektur dari Anatolia.

\section{PERKEMBANGAN DAKWAH DI TURKI}

Dalam perkembangan dakwah di Turki, strategi yang digunakan adalah tidak memaksa dalam berdakwah dan menunjukan sikap toleransi, melalui strategi ini dakwah di Turki dapat berjalan dengan baik. Selain strategi ini kita mesti tau tentang karakter dan watak orang-orang Turki yaitu disiplin dan taat kepada aturan yang berlaku.

Dari watak yang dimiliki orang-orang Turki tersebut memberi peluang penyebaran dakwah akan muda di Turki, orang-orang Turki berpendapat bahwa dakwah merupakan hal yang terbaik untuk disampaikan kepada masyarakat. Jika ada yang berniat masuk Islam, mereka akan disambut dengan baik dan akan dibantu dalam kehidupannya baik itu pemahaman agama begitu juga berkaitan dengan kebutuhan hidupnya. Begitu juga ajakan untuk masuk Islam selalu dilakukan agar semangkin banyaknya orang-orang Turki untuk memeluk agama Islam.

Kegiatan dan perkembangan dakwah di Turki didukung oleh agama Katolik dalam arti kata ibadah yang dilakukan oleh orang penganut agama Katolik sangat berbelit-belit penerapannya, banyak dari kalangan bawa Katolik yang tidak bisa memahami dan tidak bisa melakukan rangkaian ibadahnya. Hal ini yang membuat orang-orang Turki yang beragama Katolik banyak masuk Islam karena orang Islam menyediakan wadah untuk membimbing para mualaf dalam menjalani ajaran Islam, tidak hannya dari kalangan bawa saja yang masuk Islam, namun dari kalangan tinggi Katolikpun banyak yang masu Islam, apalagi sejak jatunya Konstantinopel ke tangan Turki Utsmani, banyak kalangan atas Katolik yang masuk Islam seperti keluarga kaisar Palaeologus dan cendekiawan George Amiroutzes dari Trebizond.

Pada masa Turki Utsmani ini, agama Islam menjadi tempat perlindungan bagi para muallaf, sehingga banyak orang yang memilih untuk masuk agama Islam. Selain itu, bagi kalangan penganut 
agama Katolik yang tidak tahan terhadap dokrin ajarannya dan adanya sistem kasta secara tidak lansung beransur-ansur masuk Islam.

Dalam buku yang ditulis oleh Thomas W. Arnold, yang berjudul The Preaching of Islam, menceritakan tentang penduduk yang didakwai Utsmani seperti penduduk Albania, Serbia, Bosnia, dan Kreta. Wilayah ini merupakan wilayah taklukan Turki utsmani, namun dari segi keagamaan mereka masih memeluk keyakinan agama Katolik.

Bangsa Albania, bangsa ini merupakan bang yang menduduki daerah pergunungan sepanjang pantai timur Adriatik dari Montenegoro sampai Teluk Arta. Albania merupakan salah satu ras Eropa yang pertama dan masih tergolong dalam bangsa Arya. Negeri ini ditaklukan oleh Utsmani tahun 1387 M, tetapi mereka menarik diri dan berkuasa tahun 1424 M. Tahun 1444 M, Albania memerdekakan diri di bawah kepemimpinan George Casriota. Wilayah yang dikuasainya kembali di taklukan Turki Utsmani pada tahun 1467 M. Setelah Turki utsmani menguaasai kembali negara ini banyak orang yang masuk Islam.

Perkembangan Dakwah ke Serbia, dakwah ke kota ini dimulai setelah perang Kosovo tahun 1389 M. Pada peristiwa perang ini kaum bangsawan memilih untuk berlindung kepada negara Katolik. Namun bangsawan ini masuk Islam supaya bisa mempertahankan kebangsawanannya. Ada juga dari kalangan bangsa Serbia ini yang tetap mempertahankan kebangsawanannya agar tradisi mereka tetap bertahan, sehingga mengakibatkan perkembangan Islam berjalan lambat di kota ini.

Bosnia, secara umum pemahaman orang Bosnia adalah Bogomile, pemahaman ini adalah bagian dari sekte atau ajaran agama Katolik yang pemahaman ini dianggap sesat oleh Paus. Pada abad XV kaum Bogomile mengalami penderitaan dari Bosnia, mereka meminta bantuan kepada Utsmani. Pada tahun 1463 M, Sultan Muhammad II mengarakan tentaranya untuk menyerang Bosnia sehingga tumbanglah kekuatan Bosnia. Kekalahan
Bosnia ini memberi dampak kepada umat Islam yaitu banyak keturunan Bosnia memeluk agama Islam.

Kreta, pada awalnya negara ini dikuasai oleh Vinesia. Negara ini dapat ditaklukan oleh Turki Utsmani pada tahun $1669 \mathrm{M}$ melalui pengepungan terhadap kota Candia lebih kurang tiga tahun. Penaklukan ini bukan pertama kalinya, negara ini sudah ditaklukan dan tunduk kepada kekuatan Islam pada tahun $825 \mathrm{M}$ sampai tahun $961 \mathrm{M}$. Negara ini sudah dikuasai oleh orang Islam, hampir seluruh warga Kreta masuk Islam dan Gereja diganti dengan masjid. Kalau kita mau melihat empat negara yang diceritakan di atas sampai saat ini masih memeluk agama Islam, ini sebagai bukti bahwa Turki Utsmani memberi pengaruh terhadap perkembangan agama Islam di empat negara tersebut.

\section{BERAKHIRNYA DINASTI UTSMANI}

Dinasti Turki Utsmani mulai mengalami kemunduran sejak meninggalnya Sultan Sulaiman Al-Qanuni tahun 1566 M. Namun pada saat awal ini, kemunduran dinasti Turki Utsmani belum begitu tampak karena begitu luasnya wilayah kekuasaan Utsmani. Sebagai pengganti Sultan Sulaiman Al-Qanani ditunjuk Sultan Salim II yang berkuasa dari tahun 1566-1574 M. Pada masa pemerintahan Sultan Salim II terjadi perperangan antara armada laut Utsmani dengan armada laut gabungan (Spanyol, Bundukia, Sri Paus, serta pendeta Malta yang dipimpin oleh Don Juan dari Spanyol.

Pertempuran gabungan ini terjadi di Selat Liponto (Yunani). Pada pertempuran ini, karena begitu kuatnya gabungan tentara yang menyerang Utsmana sehingga tidak mampuh untuk menahan serangan yang terjadi dan akibatnya pada pertempuran ini Turki Utsmani mengalami kekalahan dan wilayah Tunisia dikuasai aleh musuh. Pada masa pemerintahan Sultan Salim II, beliau dikenal dengan orang yang lemah dalam 
memerintah dibandingkan pemerintah sebelumnya, pada masanya pemerintahannya, mampu menaklukan Kaukasus dan menguasai Tiflis di Laut Hitam tahun 1577 M, dan Bosnia 1593 M. wilayah yang mulanya sudah ditaklukan dan dikuasai Turki Utsmani kembali lepas karena sikapnya yang kurang baik dan lemahnya dalam memerintah.

Pemerintahan Turki Utsmani semangkin lemah hingga pemerintahan Sultan Muhammad III tahun 1594-1603 M. Begitu banyaknya ancaman dan serangan dari piham musuh, kondisi Utsmani dalam keadaan melemah, akhirnya Turki Utsmani diserang oleh Australia, keaadaan Turki Utsmani semangkin melemah dengan naiknya Mustafa I sebagai pemimpin (1617-1617 M). Gejolok politik dalam pemerintahan ini tidak bisa diatasinya sehingga keluar fatwa untuk Mustafa I turun dari jabatannya, dan digantikan oleh Utsman II tahun 1617-1622 M.

Pada masa pemerintahan Sultan Ibrahim tahun 1639-1648 M, terjadi perperangan antara orang Vinesia dengan Turki di Siprus, pada tahun 1699 M, terjadi sebuah perjanjian yang disebut dengan Korlowith isinya antara lain memaksa Sultan untuk menyerahkan wilayah Hunggaria, Slovania dan Kroasia kepada Habsburg, Podolia, Ukraina, Morea dan sebagian Dalmatia kepada Vinesia.

Keadaan Turki Utsmani semangkin melemah karena banyak tekanan dari berbagai penjuru, pada tahun, $1770 \mathrm{M}$, tentara Rusia Mengalahkan Utsmani dalam perang yang terjadi pantai Asia Kecil. Namun tentara Rusia dapat dikalahkan oleh Turki Utsmani yang dipimpin oleh Sultan Mustafa III tahun 1757-1773 M.

Setelah berakhir kepemimpinan Mustafa III digantikan oleh Sultan abdul Hamid yaitu dari tahun 1773-1788 M, sultan ini dikenal dengan sultan yang lemah dalam pemerintahan Turki Utsmani. Pada masa pemerintahannya terjadi sebuah perjanjian yang disebut dengan perjanjian Kinarja di Kutcuk. Dalam perjanjian yang dilakukan ini sangat merugikan bagi Turki Utsmani, di antara isi perjanjiannya adalah sebagai berikut:

Turki Utsmani harus menyerahkan benteng yang ada di laut Hitam kepada pihak Rusia dan memberi kebebasan kepada armada Rusia untuk melintas selat perhubungan laut hitan dengan laut putih. Selain itu, Turki Utsmani harus mengakui kemerdekaan Kirman (Crimea).

Dalam uraian di atas, itulah bentuk-bentuk kemunduran dinasti Turki Utsmani, selain itu, satu persatu wilayah yang sudah dikuasai Utsmani kembali lepas dan di kuasai oleh negara lain terutama yang ada di wilayah Eropa. Dinasti Utsmani berakhir sejak berdirinya Republik Turki tahun 1924 M, kemudian mengangkat Mustafa Kemal Attaturk sebagai presiden pertama Turki.

Faktor utama runtuhnya Dinasti Utsmani adalah begitu luasnya wilayah kekuasaan Utsmani sehingga susah untuk dikendalikan perkembangannya dan mempertahankannya. Selain itu, Lemahnya para penguasa Utsmani dari tahun ke tahun yang menyebapkan banyaknya pemberontakan dari berbagai negara lawan. Lemahnya pemerintahan Utsmani terjadi sejak meninggalnya Sultan Sulaiman Al-Qanuni, banyak kekacauan yang muncul dan tidak dapat diatasi bahkan semangkin berlarut-larut.

Tambahan lagi, faktor wilayah kekuasaan yang luas dan banyak penduduk (heterogen), hal ini membuat pemimpin Utsmani susah untuk mengendalikan perkemangan masyarakatnya, baik itu dari segi agama, budaya, ras, maupun adatistiadat yang mereka miliki.

Adanya budaya korupsi bagi kalangan penguasa, cara ini membuat pemimpin yang terpilih akan memberlakukan secara turun temurun. Bagi orang-orang Usmani yang mau menjadi pemimpin dalam bidang apapun mesti membayar terlebih dahulu kepada penguasa pada saat itu. Budayah ini membuat lemah pemerintahan dan kepemimpinan yang sedang berjalan karena mereka tidak lagi 
memikirkan masyarakat melainkan dirinya dan keluarganya.

Terjadinya pemberontakan tentara Jenisseri, sebagaimana kita uraikan di atas, perkembangan dan ekspansi Utsmani sangat didukung oleh tentara Jenisseri. Melalui tentara Utsmani yang kuat ini dapat menaklukan berbagai wilayah, namun kali ini mereka sendiri yang memberontak terhadap pemerintahan Utsmani. Pemberontakan tentara Jenisseri ini terjadi sebanyak empat kali yaituh pada tahun 1525, 1632, 1727 dan tahun $1826 \mathrm{M}$.

Melemahnya ekonomi Utsmani, melemahnya ekonomo Utsmani memberi dampak yang besar terhadap perkembangan dinasti ini, melemahnya ekonomi Utsmani disebapkan terlalu banyak pemberontakan sehingga keuangan negara habis untuk pembiayaan perang, perekonomian merosot, pendapatan negara sedikit, namun kebutuhan belanja negara semangkin meningkat.

Terakhir, faktor keruntuhannya adalah terjadinya perkembangan dalam bidang ilmu pengetahun. Dalam ilmu pengetahuan Turki Utsmani dianggap lemah, hal ini disebapkan karena Utsmani lebih fokus perkembangan dalam bidang militer dan sedikit memperhatikan ilmu pengetahuan. Akibat lemahnya pengetahuan, sehingga Utsmani tidak mampu membentengi serangan musuh yang memiliki senjata yang begitu canggi.

\section{DAFTAR KEPUSTAKAAN}

Badriyatim, Sejarah Peradaban Islam, Jakarta., Rajawali, 1999., hlm. 129

Samsul Munir Amin, Sejarah Dakwah, Jakarta., Amzah, 2015, hlm. 140

Thomas W. Arnol, Sejarah Dakwah Islam, Jakrta., Wijaya, 1981., hlm. 130. Lihat juga dalam buku Harun Nasution, Islam Ditinjau Dari Berbagai Aspek, Jakarta, UI Press, 1985., hlm. 84
Ajid Thohir, Perkembangan Peradaban Di Kawasan Dunia Islam. (Jakarta: PT. Raja Grafindo Persada, 2004)

Binnaz Toprak, Islam dan Perkembangan Politik di Turki, Yokyakarta., Wacana, 1999., hlm. 44

Ahmad Syalabi, Sejarah dan Kebudayaan Islam Imperium Turki Utsmani, Jakarta, Kalam Mulia., 1988., hlm. 46

Thoma W. Arnol, Sejarah Dakwah Islam, Jakarta, Wijaya., 1981. Hlm. 141

Hamka, Sejarah Umat Islam, Jilit III, hlm. 232.

Hasan Ibrahim Hasan, Sejarah Dakwah, hal. 151. Lihat juga dalam buku yang ditulis oleh Carl Brockmann, History Of Islamic, London., Rotledge and Kegan Paus, tahun 1982, hal. 328

Ahmad Syalabi, Sejarah dan Kebudayaan Islam, Imperium Turki Utsmani, Jakarta, Kalam Mulia, 1988., hlm. 49 